\title{
Smart Meters Tackling Energy Poverty Mitigation: Uses, Risks and Approaches
}

\author{
Lluc Canals Casals \\ Universitat Politècnica de \\ Catalunya; \\ Catalonia Institute for Energy \\ Research \\ Sant Adrià de Besòs, Spain) \\ lcanals@irec.cat 0000-0002- \\ 4791-9917
}

\author{
Sergio Tirado Herrero \\ Institute of Environmental \\ Science and Technology (ICTA) \\ Universitat Autònoma de \\ Barcelona (UAB) \\ Cerdanyola del Vallès, Spain \\ 0000-0003-3187-1039
}

\author{
Mattia Barbero \\ Energy Systems Analytics \\ Catalonia Institute for Energy \\ Research \\ Sant Adrià de Besòs, Spain \\ mbarbero@irec.cat
}

\author{
Cristina Corchero \\ Energy Systems Analytics \\ Catalonia Institute for Energy \\ Research \\ Sant Adrià de Besòs, Spain \\ ccoerchero@irec.cat 0000-0002- \\ $8465-0830$
}

\begin{abstract}
Big data analysis is becoming an increasing field of interest for research to analyse, identify and predict final user's behaviour. For this reason, in the energy sector, smart metering is generally used to find new business opportunities and, theoretically, it is said that it could also help to fight energy poverty issues. Nonetheless, when tackling social injustice issues, the deployment of massive technology might also bring other side effects. This study analyses the capability of smart metering to mitigate energy poverty in Europe according to the current approaches of projects and the risks it might bring to the more vulnerable layers of our society.
\end{abstract}

Keywords - Smart Meters, Energy Poverty, Social Washing

\section{INTRODUCTION}

Eurostat data indicate that $22.4 \%$ of the EU population is at risk of poverty or social exclusion [1]. This massive problem, which is unevenly distributed across Europe [2], is difficult to fight as a whole without substantial changes in the economic system. However, as poverty has multiple effects on people suffering it (health, social, energy, financial, etc.), regions and countries began to distinguish among forms of material and monetary deprivation in order to provide regulatory frameworks to facilitate the mitigation of its consequences on wellbeing.

This is how the concept of Energy Poverty (EP) first appeared and specific legislation was passed at the EU level back in 2009 [3] and later became an important aspect of the EU's 'Clean Energy for All Europeans' package [4]. Although there is an ongoing discussion on definitions and driving forces, with most conceptualizations insisting on the idea of energy inefficient housing and low incomes as key causes, it is widely agreed that "energy poverty can be seen as situation in which a household lacks a socially and materially necessitated level of energy services in the home" [5]. While energy poverty definitions refer to all domestic energy services and energy sources, electricity stands out as an essential household supply for a life with health and dignity.

In a developed world context such as the one we examine in this paper, electricity is a non-substitutable energy carrier for

This study was possible thanks to the EmpowerMed project ID 847052 funded by the H2020 programme of the European Comission. Lluc Canals Casals also thanks the Serra Húnter programme. powering household appliances and telecommunication devices, for keeping the lights on and for providing domestic heat in absence of natural gas or other fuels. Even if electricity may not be the largest energy expense of an average household in Europe, it is the most necessary supply because the energy services it provides are indispensable (e.g. food conservation and indoor lighting) and also because it cannot be easily replaced by other energy carriers. For this reason, all OECD countries report rates of household access to electricity of nearly $100 \%$ [6] while access to natural gas and other forms of networked energy supply (e.g., district heating) largely vary across places and regions.

Like many other local and regional administrations, the EU has yearly launched Coordination and Support Action calls within the Horizon 2020 program since 2018 specifically aimed on mitigating household energy poverty (call H2020-LC-SC32018-2019-2020). Many of the funded projects still focus the attention on energy efficiency measures to tackle this objective and, some of them, consider the use of smart meters an interesting approach to analyze.

Individual energy consumption data collected through smart meters gives way to advanced data capturing and processing technologies such as big data and block chain enabled by the continuously increasing computing capabilities of IT systems. In the EU, the uptake of smart meters is proceeding unevenly with Denmark, Italy, Spain, Sweden, the UK, France, Netherlands, Austria and Greece likely achieving a wide-scale rollout by 2020, whereas other Member States are only expected to do so after 2030 [7]. This form of 'digital transition' follows an EU mandate according to which at least $80 \%$ of electricity meters need to be replaced with smart meters by 2020 "wherever it is cost-effective to do so". The European Commission estimates that the smart metering and smart grids rollout can reduce total EU emissions by up to $9 \%$ and reduce annual household energy consumption to a similar extent [8].

Thus, it is believed that big data mining from Smart Meter readings could provide valuable information to utilities about the consumption patterns of households allowing the identification of people at risk. Then, the utility could inform the corresponding public administration that would be the actor in charge of taking actions. 
Some initiatives have large energy utilities in their partnership, such as SocialWatt (H2020) [9] or CONFIA (meaning 'trust' in Spanish) project, which states in the press note that it will use blockchain technology in Malaga, Spain as a pilot experience [10]. Although these companies have an enormous capacity to really ease the situation of vulnerable households, reason why it might be interesting to have them in the consortia, in some cases they are the ones putting obstacles and hindering the application of advanced vulnerable customer protection regulations, such as law 24/2015 from the Catalan parliament, which forbids the disconnection from basic domestic supplies (electricity, natural gas and water) of households identified to be 'at risk of residential exclusion' by social services (evidences are presented in section II).

The use of smart meters can be targeted for explicitly sensitive approaches to the needs and concerns of vulnerable households to tackle energy poverty. This is the case of the EmpowerMED (Empowering women to take action against energy poverty in the Mediterranean) consortium, which is the frame of this study. In this project, the use of smart meters is meant to provide useful, actionable information and tips about how to reduce the electricity bill to vulnerable people by performing fast, automated and easy-to-understand energy audits. To do so, several side effects problems considering the use of smart metering were identified during the implementation phase.

First, several difficulties were found when trying to have access to the individuals, presented in further details in section III. Then, additional considerations appeared when applying the General Data Protection Regulation (GDPR) active since 2012 [11], which states that data should be used after "explicit and provable consent".

Knowing that EP has multiple driving factors, it is necessary to discuss if the massive smart meter roll out in some EU countries contributing to identify and support people affected by EP can effectively contribute to tackling this form of material deprivation. Moreover, it is argued that currently dominant, profit-oriented forms of smart meter deployment serve 'social washing' strategies of utility companies involved in the roll out and preclude pursuing alternative smart metering systems based on consumer-centered approaches that protect the interests of all consumers, especially of the most disadvantage.

This study first presents the reality of EP in Barcelona's pilot site (section II) to further perform a deep analysis of the critical situations encountered during the deployment of EmpowerMED smart reading approach in this pilot site (Section III). Then it compares the approach and partners of other projects around EU (section IV) to finally analyze the fitness of smart meter technologies as an adequate tool for energy and social analysis.

\section{ENERGY POVERTY IN BARCELONA}

A sizeable fraction of the population of Barcelona experiences energy poverty as measured by 'consensual' or selfreported indicators [12], [13]. According to the Barcelona 799household sub-sample of the 2016 Spanish Survey on Income and Living Conditions (SILC) dataset, as many as 170,000 persons (11\% of the city's 1.54 million population) couldn't afford to keep their home adequately warm in winter and/or were in arrears on utility bills in 2016. In addition, 11 respondents (1\% of Barcelona's SILC 799 household subsample) declared having had their energy supply interrupted at least once in the previous 12 months due to financial difficulties. The latter figures suggest that thousands - if not tens of thousands - of residents in Barcelona did not have their domestic energy supply guaranteed back in 2016 [14].

Being disconnected from the energy supply, and/or threatened with disconnection, is among the worst consequences of a household's inability to afford domestic energy. An unexplored aspect of EP, they constitute a turning point in a household's energy biography as they entail significant risks (e.g., of house fires because of the indoor combustion of fuels or the use of candles as a substitute for electric lighting) and produce exclusionary effects.

All in all, forced disconnections critically endanger the health and well-being of affected households [15], [16]. In Barcelona, a non-random 100-people survey of people at risk of housing eviction and/or utility disconnection has found poor mental health conditions as measured by the Goldberg-Shapiro scale in $70 \%$ of men and $83 \%$ women in such circumstances. These percentages are practically four times higher than the average scores for the whole population of Barcelona $-16 \%$ for men and $20 \%$ for women - and speak loudly of the significant emotional and mental health burden of housing and energyrelated precariousness [17].

Regarding household electricity use, in Barcelona as in other parts of Mediterranean, many dwellings often lack pre-installed central or collective heating systems (e.g., a natural gas boiler that supplies heat to radiators across all rooms as well as sanitary hot water) and therefore households are forced to rely on electricity as a source of domestic heat [14]. These conditions disproportionately affect vulnerable households since electricity is significantly more expensive than alternative energy carriers such as natural or bottled gas. The analysis of a sample of 102 households assisted by an EP pilot project of the Barcelona City Council in 2015-2016 found a population heavily dependent on inefficient electricity-based portable resistance heaters or radiators (69\% of all assisted households). Significant shares of electricity-based water heating $(30 \%$ electric boilers) and cooking ( $31 \%$ of electric hobs) were also reported by this $102-$ household sample [18].

In response to these grim realities, the Barcelona-based Platform for People Affected by Mortgages (Plataforma de Afectados por la Hipoteca, PAH) and the Alliance against Energy Poverty (Aliança contra la Pobresa Energètica, APE) and the human rights research and advocacy centre Observatori DESC promoted a people's legislative initiative later passed unanimously by the Parliament of Catalonia in June 2015 as Law 24/2015 of urgent measures to tackle housing and energy poverty emergencies. A unique piece of legislation in Spain and the whole EU, it forbids the eviction and disconnection of Catalan households considered to be at risk of housing-related exclusion by social services.

While there's evidence that Law 24/2015 has significantly reduced disconnections from water supply [19], it is perceived that energy providers are more reluctantly complying with its requirements. The most blatant case is Rosa Pitarch - an 81-year 
old woman from Reus (100 km south of Barcelona) - who died as a result of a fire occurred in her apartment located in the city of Reus. Rosa had been using candles to lit her home (one of which set her mattress on fire) for two months after having her electricity supply disconnected as she was unable to pay the bills. As she was trying to flee the fire, she fell and died from smoke inhalation. Rosa was a partially disabled person attended by the municipal social services since 2013. According to the Reus local council, Rosa's electricity provider Gas Natural Fenosa (now Naturgy) had cut her off without informing the municipal social services as it is required by Law 24/2015. Consequently, the Generalitat de Catalunya - the Catalan government - imposed a half million Euro fine to Gas Natural Fenosa in June 2017 after finding evidence of 'serious misconduct' - a decision that has been later appealed by the utility company. Despite serious infringements such as the case of Rosa Pitarch, it is believed that Law 24/2015 has effectively stopped or prevented tens of thousands of gas, electricity and domestic water supply disconnections in Barcelona and across Catalonia.

\section{THE EMPOWERMED PROJECT DEPLOYMENT IN BARCELONA'S PILOT SITE}

The EmpowerMed project is a consortium of social and energy engaged actors with practical EP experience in Europe's Mediterranean coastline region (Albania, Croatia, France, Italy, Slovenia and Spain) in recent years. EmpowerMed puts together the expertise and capabilities of the project's partner organizations to effectively tackle EP in one urban pilot site of each of the 6 project countries. It aims to assess and maximize the effectiveness of the following approaches for EP alleviation: household visits, collective advisory assemblies, smart metering and thermal monitoring.

Among the practical implementation approaches mentioned above, smart meters' reading is most relevant for the Barcelona pilot site (Italy will also implement its own smart meter pilot in the city of Padova within EmpowerMed). The way this pilot site reaches EP affected people is through the collective advisory assemblies of the Barcelona-based Alliance against Energy Poverty (APE). These meetings follow a peer-to-peer strategy and a collective intelligence methodology through which knowledge accumulates as new cases arrive and practical solutions are suggested by assembly participants, who in many cases have experienced or still experience similar conditions of energy precariousness.

While non EP-affected activists play an important role as mediators and spokespersons of the Alliance, APE's assemblies take place without explicit formal leadership on purpose so that participants affected by EP become empowered through finding solutions to their own and others' domestic energy issues and also by becoming activists. Then, when needed (e.g., if a household that has requested APE's support is threatened with disconnection by a utility service provider), strong mobilization of a network of engaged persons and organizations is possible.

Participants in APE's collective advisory assemblies represent a severely affected population at risk of energy exclusion.
TABLE I. FE FREQUENCY OF ENERGY POVERTY ISSUES REPORTED BY PARTICIPANT HOUSEHOLDS IN APE COLLECTIVE ASSEMBLIES

\begin{tabular}{|l|c|c|c|}
\hline \multicolumn{1}{|c|}{ Reported issue } & Electricity & Natural gas & Water \\
\hline Disconnection or no access & $25 \%$ & $3 \%$ & $13 \%$ \\
\hline Cutoff warning & $8 \%$ & $3 \%$ & $3 \%$ \\
\hline Arrears or failed payment & $23 \%$ & $8 \%$ & $12 \%$ \\
\hline
\end{tabular}

A semi-quantitative transcription and analysis of issues reported in 78 'energy poverty chronicles' (i.e., short cases' summaries of APE's assemblies) corresponding to 286 households that attended those meetings between November 2014 and March 2018 [20] can be seen in Table I. These figures indicate that $25 \%$ of the 286 APE households in that period reported utility-enforced disconnections or no access to the electricity supply (versus 3\% of natural gas and $13 \%$ of water). Electricity was also the most problematic supply for cutoff warmings, arrears and failed payments.

Through EmpowerMed, the use of smart meter reading is proposed to participants of APE collective assemblies that volunteer for their household electricity consumption data to be analyzed, such as the maximum power demand per month (Fig. 1) or the hourly electricity consumption per day (Fig. 2), to present possible economic and consumption savings.

With that, it is possible to identify if the power contracted by people is in-line with their needs, as in the example of Fig. 1, or if they can decrease this value to adapt it to their reality (considering that the costs per $\mathrm{kW}$ contracted in Spain is around $4 €$, which means about $50 €$ per year).

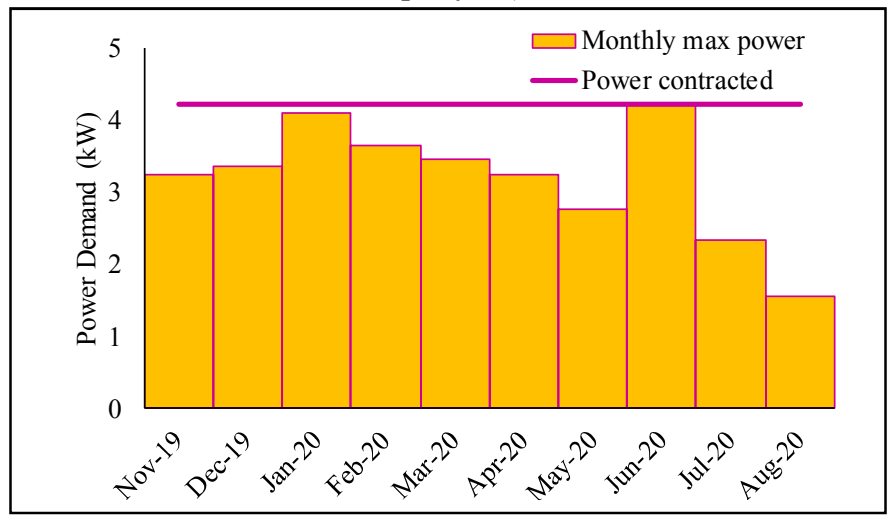

Fig. 1. Maximum power demand downloaded from a volunteer

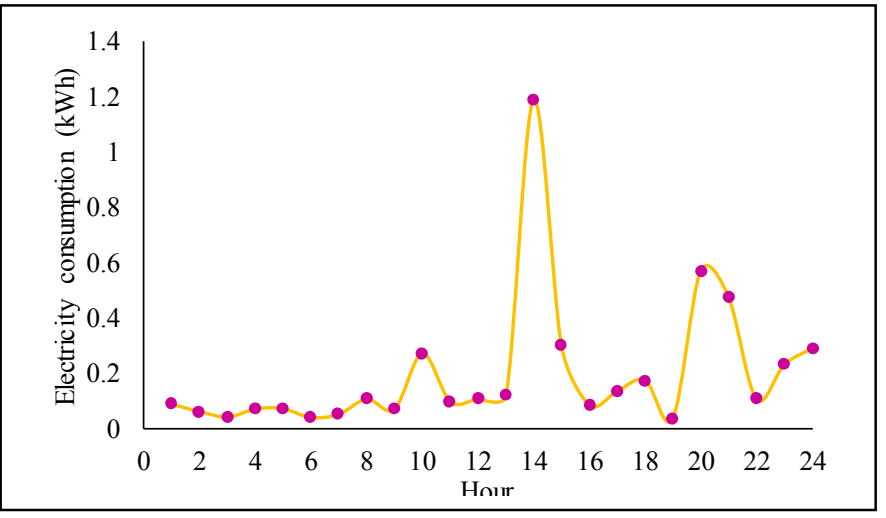

Fig. 2. Example of hourly electricity consumption for a day in May. 
The analysis of the daily consumption patterns (Fig. 2) is useful to determine the type of tariff that best suits each household and, in some cases, it might also be used to suggest changes during peak energy consumptions.

It was during the development of the tool to be used in the collective assemblies that a first identification and assessment of factors and conditions for the use of smart meters with EP alleviation purposes in Spain was done.

In the first place, difficulties were found when trying to reach and work with raw data from the smart meter of ÊPaffected people. In Spain, the information is sent directly from the smart meter to the distribution company who owns (and rents) most of metering devices. Note that, in the Spanish context, electricity distribution is organized in regional monopolies in territories where most domestic consumers resemble a 'private' asset of the dominant supplier.

Therefore, for EmpowerMed researchers to access individual electricity consumption data of volunteer APE households for the first time (note that most of people never tried to do so before the project started), the domestic supply contract holder needs to do the following steps and wait for several hours (or days) for the online activation of the account:

1. Have an e-mail account.

2. Fill-in the on-line registration form (which asks for personal needed data to relate the supply contract holder with its corresponding smart meter).

3. Upload a scan of their National Identity Document

4. Wait for several hours (or days) to have access to the data (this is the time needed by the distribution company to validate the data).

5. Receive a confirmation e-mail with their credentials to enter the web portal and physically access their electricity consumption data.

Then, access is limited to a web portal were one can take a look at the information related to the household's smart meter and manually discharge monthly hourly and quarter of hour readings through a *.csv file. Note that there's no free Application Programming Interface (API) that allows an automated discharge of the energy information and, when asked for it, the distribution company requests a fee to give access to it. Alternatively, one may ask for access to the smart meter consumption data through the Spanish Transmission Systems Operator (TSO) - the partly state-owned Red Eléctrica de España (REE) - who acknowledges that the ownership of this data is of the client and that access should be granted in different modes. However, the reception of information using this channel may require even longer time, as REE acts as an intermediary between the domestic client and the distribution company reluctant to give this information freely, although as stated before, smart meters are paid by the consumers.

Planning to use smart-meter reading in Spain and Italy in EmpowerMed makes sense considering the latest EU smart metering benchmark assessment [7], as these are two of the few countries that have deployed almost $100 \%$ of smart meters among domestic electricity consumers. However, taking a deeper look into the purposes of the ongoing digitalization of electricity consumption metering, one can see that, in the case of Spain, the focus is on digitalizing the "distribution grid and optimize network operations" and for "retail markets to foster innovation and new services by private actors". This benchmark also analyzed which countries considered smart metering as "support actions tackling fuel poverty" and, for Spain, this line was clearly unmarked. In fact, only 7 of the 28 countries have a tick on this latter concept while 26 over 28 tick the "distribution grid and optimize network operations".

As a consequence, there's no way for third parties (such as EmpowerMed researchers), even having the personal consent from the user, to access and use this data in an automated way without having first an agreement with the distribution company. Therefore, a process that could be done in about minutes needs a 2-session process (one for activating the account and another for downloading and processing results).

Finally, through the participation in these collective advisory assemblies, it was learnt that many irregular situations in relation to electricity supply exist. This could be the case, for instance, of households living in informal housing arrangements such as evicted families forced to irregularly occupy a dwelling due to insufficient social housing provision. In these cases, the use of smart meters is impossible through the EmpowerMed project, as the supply contract holder of the smart meter is clearly not the actual user.

\section{Projects Using Smart Metering, Big Data AND BLOCKCHAIN TECHNOLOGIES}

Energy poverty, as a widespread social concern, acts as an enabler for projects with different purposes and partnerships. Table II presents a number of selected EP related projects along with their EP alleviation approach, partner typologies and funding sources.

Seeing through the different approaches and partners involved, it is possible to have a first assessment of the project's objectives in regard to the use of smart meter technologies.

In Table II, EU public funded projects have a grey background while private funding is in white. Although there are other EP related projects, such as ASSIST2gether, REACH, ACHIEVE among others, this table presents those that use monitoring equipment through smart meters and data loggers, or where new digital technologies are involved.

Note that, although most of projects consider meter reading (MR), all of them, except EmpowerMed, use specially dedicated equipment or tools for that purpose and none of them uses the day-to-day smart meters already installed by the utilities. Only in market-related or price-dynamic projects (not tackling EP directly), this approach might be followed through multi-party data sharing (as in the Synergy project)

From Table II, it can be sensed that when private companies are the majority of partners in the project, the approach is more technologically intensive or it is oriented towards the utility expecting to have a positive impact on EP affected through energy savings (as in SocialWatt).

Such expectations are at odds with the reality of EP-affected households that often consume visibly less than non-affected households - or even under-consume below acceptable levels of energy service provision [30]. 
TABLE II. FUNDED PROJECTS

\begin{tabular}{|c|c|c|c|c|c|c|}
\hline Name & $\begin{array}{c}E P \\
\text { approach }\end{array}$ & $M R^{a}$ & $\begin{array}{c}\text { Data } \\
\text { mining }\end{array}$ & $\begin{array}{c}\text { For-profit } \\
\text { Partners }\end{array}$ & $\begin{array}{l}\text { Fund } \\
\text { (ME) }\end{array}$ & Ref \\
\hline $\begin{array}{l}\text { Smart- } \\
\text { Up }\end{array}$ & $\begin{array}{l}\text { Through } \\
\text { In-house } \\
\text { displays }\end{array}$ & Yes & No & Yes $^{\mathrm{b}} 64 \%$ & 0.8 & [18] \\
\hline $\begin{array}{l}\text { Nobel } \\
\text { Grid }\end{array}$ & $\begin{array}{l}\text { Monitor \& } \\
\text { control }\end{array}$ & Yes & No & Yes $43 \%$ & 11.7 & [19] \\
\hline $\begin{array}{l}\text { Energia } \\
\text { su } \\
\text { misura }\end{array}$ & $\begin{array}{l}\text { Monitor \& } \\
\text { efficiency }\end{array}$ & Yes & No & $\mathrm{Yes}^{\mathrm{b}}$ & - & [20] \\
\hline BECA & $\begin{array}{l}\text { Web page } \\
\text { Monitor \& } \\
\text { control }\end{array}$ & Yes & No & Yes $57 \%$ & 2.7 & [21] \\
\hline $\begin{array}{l}\text { Syner- } \\
\text { gy }\end{array}$ & $\begin{array}{l}\text { Big data } \\
\text { multi- } \\
\text { party data } \\
\text { sharing }^{c}\end{array}$ & Yes & Yes & Yes $63 \%$ & 9.9 & [22] \\
\hline STEP & $\begin{array}{l}\text { behaviour } \\
\text { al change } \\
\text { through } \\
\text { visits }\end{array}$ & No & No & No & 2 & [23] \\
\hline $\begin{array}{l}\text { Empow } \\
\text { erMed }\end{array}$ & $\begin{array}{l}\text { Visits \& } \\
\text { monitor }\end{array}$ & Yes & Yes & Yes $14 \%$ & 2 & [24] \\
\hline $\begin{array}{l}\text { Social- } \\
\text { Watt }\end{array}$ & $\begin{array}{l}\text { Tools for } \\
\text { utilities } \\
\text { and } \\
\text { suppliers }\end{array}$ & Yes & Yes & Yes $58 \%$ & 2 & [8] \\
\hline $\begin{array}{l}\text { Therm } \\
\text { CERT }\end{array}$ & $\begin{array}{l}\text { Satellite } \\
\text { infra-read } \\
\text { imaging }\end{array}$ & No & Yes & Yes & $? ?$ & [25] \\
\hline Confia & $\begin{array}{l}\text { Block- } \\
\text { chain }\end{array}$ & No & No & Yes & $? ?$ & [26] \\
\hline
\end{tabular}

c. One private energy seller partner (Urbener) indicates that their measures will help to alleviate EP, although it is not readable in the scope of the project

Note also that when the consortium has for-profit partners, they tend to consume more budget than the socially-related organizations in the project.

In private or bilateral funding from municipalities, the use of advanced technology approaches for simple problem resolution is often observed. These projects seem basically done for socialwashing purposes. For instance, the Confia project relies on blockchain technologies to inform the municipality of Malaga in Andalusia, Southern Spain, when a domestic customer falls into arrears to accelerate the social electricity tariff allocation. When the project agreement was signed, it appeared in all the press and on-line media $(80 \%$ of the first, second and third entrance on Google with Blockchain and "pobreza energética"), while none of the H2020 funded projects has so many entrances.

Other blockchain initiatives (which are not projects as such and are not included in Table II) to fight EP were proposed by other private companies, such as the platform Powing from Enagás or a blockchain challenge from Caixabank. In this same direction, the ThermCERT initiative, which has the utility E.ON as main partner, is pioneering the use of military technology as satellite infra-red imaging technologies for identifying households at risk of EP through energy efficiency assessments.

\section{DISCUSSION / CONCLUSIONS}

Against aspirational claims about their role in addressing global energy challenges, critics have argued that smart energy technologies may reinforce unsustainable energy consumption patterns, are not easily accessible by vulnerable consumers, and do little to help the energy poor secure adequate and affordable access to energy at home [31]-[33]. Concerns exist also around their enabling role for dynamic pricing systems becoming dominant in energy markets. Additionally, massive amounts of data on household energy use collected by smart meters are being rapidly commodified - a trend referred to as 'datafication' or recording of various aspects of life into computerised data for their transformation into new forms of value [34]. The mass rollout of smart metres in EU Member States raises the following concerns regarding domestic energy vulnerability:

- Smart metering devices installed by default do not always provide users with real-time information on consumption, prices or expenditures. On the other hand, the energy suppliers are the ones having this access to the data. This lead into major irregularities in Spain, where utilities take advantages of massive transfers from fixed to hourly tariffs without clearly indicating this to the client and absorbing most of the economic savings [35].

- They result in higher standing charges and may enable new forms of remote disconnection.

- Hourly pricing could impact negatively on vulnerable households unable to change their electricity use practices.

After analyzing the current situation in Europe and, more precisely, in Spain and the projects funded, it seems clear that when utilities participate into one EP related project, they do not clearly foresee to mitigate EP but to find the way to ensure the payments (for instance, in the Spanish context, by facilitating the access of the social electricity tariff offered by the government) or to find new business niches through advanced technology deployment that may result in misleading final clients with complex electricity supply offers.

Moreover, it was shown how utilities still put obstacles in the implementation of laws and regulations protecting vulnerable citizens from disconnections - as evidenced by the case of law 24/2015 in Catalonia. And even when the law is passed, they continue threatening clients with cuts either directly or through subcontracted debt collects [36] and forcing public authorities to keep a constant surveillance of the implementation of the law and long legal disputes [37].

In addition to that, preparatory work carried out the initial stages of the EmpowerMed project shows the difficulties to easily access smart meter data to analyze the past consumption of EP-affected households even when having their permission to access their data. Also, knowing that not all EP household are in a regular and stable situation in regard to the dwelling where they live we found that unexpected eviction-related risks arise, which should be taken into serious consideration.

As a consequence, although it seems reasonable to believe that some EP affected households consumption patterns could be identified through smart technologies, if big data is to be used, much more than just smart metering in the hands of utilities should be analyzed [38].

\section{REFERENCES}


[1] EUROSTAT, 'People at risk of poverty or social exclusion rate', 2017. https://ec.europa.eu/eurostat/statisticsexplained/index.php/People at risk_of poverty or_social_exclusion (accessed Jul. 01, 2020).

[2] S. Bouzarovski and S. Tirado Herrero, 'The energy divide: Integrating energy transitions, regional inequalities and poverty trends in the European Union', European Urban and Regional Studies, vol. 24, no. 1, pp. 69-86, 2017, doi: 10.1177/0969776415596449.

[3] European Union, 'A brief overview of the EU discourse on fuel poverty and energy poverty', 2014. https://www.energypoverty.eu/news/briefoverview-eu-discourse-fuel-poverty-energy-poverty (accessed Jan. 14, 2020).

[4] European Commission, 'Clean Energy For All Europeans COM(2016) 860 final’, pp. 1-13, 2016.

[5] S. Bouzarovski, 'Energy poverty in the European Union: Landscapes of vulnerability', Energy and Environment, vol. 3, no. 3, pp. 276-289, 2014, doi: $10.1002 /$ wene. 89 .

[6] World Bank Data, 'Access to electrricity (\% of poulation) - OECD Members'.

https://data.worldbank.org/indicator/EG.ELC.ACCS.ZS?locations=OE (accessed Oct. 01, 2020).

[7] Tractebel, 'European Smart Metering Benchmark', European Commission DG Energy - Belgium, no. June, pp. 1-129, 2019, doi: $10.5771 / 9783845266190-974$.

[8] European Commission, 'Smart grids and meters'. https://ec.europa.eu/energy/en/topics/markets-and-consumers/smartgrids-and-meters/overview (accessed Feb. 21, 2020)

[9] H2020 No845905, 'SocialWatt', https://cordis.europa.eu/project/id/845905 (accessed Sep. 03, 2020).

[10] 'CONFIA', ENDESA, 'Cttps://www.endesa.com/es/prensa/news/d201911-endesa-utilizara-latecnologia-blockchain-para-agilizar-los-casos-de-pobrezaenergetica.html (accessed Jul. 01, 2019).

[11] E. Union, Regulation 2016/679, O cial Journal of the European Union 2001. 2016.

[12] J. D. Healy and J. Peter Clinch, 'Fuel poverty, thermal comfort and occupancy: Results of a national household - survey in Ireland', Applied Energy, vol. 73, no. 3-4, pp. 329-343, Nov. 2002, doi: 10.1016/S03062619(02)00115-0.

[13] J. D. Healy, Housing, fuel poverty, and health: a pan-European analysis. England: Burlington, VT: Ashgate Pub, 2004.

[14] S. Tirado Herrero, 'Indicadors municipals de pobresa energètica a la ciutat de Barcelona', Barcelona, 2018.

[15] L. Chester and A. Morris, 'A new form of energy poverty is the hallmark of liberalised electricity sectors', Australian Journal of Social Issues, vol. 46, no. 4, pp. 435-458, Dec. 2011, doi: 10.1002/j.18394655.2011.tb00228.x.

[16] K. C. O'Sullivan, P. L. Howden-Chapman, and G. Fougere, 'Making the connection: The relationship between fuel poverty, electricity disconnection, and prepayment metering', Energy Policy, vol. 39, no. 2, pp. 733-741, Feb. 2011, doi: 10.1016/j.enpol.2010.10.046.

[17] L. Delgado, 'Radiografies de la situació del dret a l'habitatge, la pobresa energètica i el seu impacte en la salut a Barcelona', 2018.

[18] Fundació ABD /Associació Ecoserveis, 'Informe de Servei. Resultats de la Prova Pilot Punts d'Atenció a la Pobresa Energètica. 30 Novembre 2015 - 31 Març 2016.', Ayuntamiento de Barcelona, 2016.

[19] E. Domene, X. Garcia, and M. Garcia, 'La pobresa hídrica i energètica a l'àrea metropolitana de Barcelona', Bellaterra, 2018.

[20] Aliança contra la Pobresa Energètica (APE), 'Cròniques'. https://pobresaenergetica.es/category/cronica-ca/ (accessed Oct. 02,
2020).

[21] H2020 no649669, 'Smart Up'. https://www.smartup-project.eu/ (accessed Sep. 03, 2020)

[22] H2020 no646184, 'Nobel Grid', 2015. https://nobelgrid.eu/ (accessed Sep. 03, 2020).

[23] European Union Intelligent Energy Europe programme, 'Energia su Misura', 2016. http://www.rse-web.it/notizie/Energia-su-misura---percase-meno-im-popolari-a-Milano.page (accessed Sep. 03, 2020).

[24] CIP no270981, 'BECA'. http://beca-project.eu/index.php?id=659.

[25] H. No872734, 'Big Energy Data Value Creation within SYNergetic enERGY-as-a-service Applications through trusted multi-party data sharing over an AI big data analytics marketplace | SYNERGY Project | H2020 | CORDIS | European Commission', 2020. https://cordis.europa.eu/project/id/872734 (accessed Mar. 10, 2020).

[26] H2020 no847080, 'Solutions to Tackle Energy Poverty', 2019. https://cordis.europa.eu/project/id/847080 (accessed Sep. 03, 2020).

[27] H2020 no847052, 'Empowering women to take action against energy poverty in the Mediterranean | EmpowerMed'. https://cordis.europa.eu/project/id/847052/es (accessed Mar. 10, 2020).

[28] Eon, ASTROSTAT, and European Space Agency, 'ThermCERT'. https://www.astrosat.space/thermcert (accessed Mar. 09, 2020).

[29] ENDESA, 'CONFIA'. https://www.endesa.com/es/prensa/sala-deprensa/noticias/social/endesa-utilizara-la-tecnologia-blockchain-paraagilizar-los-casos-de-pobreza-energetica (accessed Mar. 09, 2020).

[30] J. P. Gouveia and J. Seixas, 'Unraveling electricity consumption profiles in households through clusters: Combining smart meters and door-to-door surveys', Energy and Buildings, vol. 116, pp. 666-676, 2016, doi: 10.1016/j.enbuild.2016.01.043

[31] S. J. Darby, 'Smart technology in the home: time for more clarity', Building Research and Information, vol. 46, no. 1. Routledge, pp. 140147, Jan. 02, 2018, doi: 10.1080/09613218.2017.1301707.

[32] S. Tirado Herrero, L. Nicholls, and Y. Strengers, 'Smart home technologies in everyday life: do they address key energy challenges in households?', Current Opinion in Environmental Sustainability, vol. 31. Elsevier B.V., pp. 65-70, Apr. 01, 2018, doi: 10.1016/j.cosust.2017.12.001.

[33] Y. Strengers, Smart energy technologies in everyday life : smart utopia? 2013.

[34] K. Cukier and V. Mayer-Schoenberger, 'The Rise of Big Data: How It's Changing the Way We Think About the World', Foreign Affairs, vol. 92. Council on Foreign Relations, pp. 28-40, doi: 10.2307/23526834.

[35] A. M. Vélez, 'Las eléctricas traspasan a millones de usuarios a las tarifas más baratas y se quedan parte del ahorro', Eldiario.es, 2019.

[36] 'Endesa y Gas Natural Fenosa subcontratan empresas y despachos de abogados que asedian familias vulnerables para conseguir el cobro de sus deudas', APE, 2019. https://pobresaenergetica.es/index.php/es/medios/comunicados/502endesa-y-gas-natural-fenosa-subcontratan-empresas-y-despachos-deabogados-que-asedian-familias-vulnerables-para-conseguir-el-cobro-desus-deudas (accessed Mar. 10, 2020).

[37] M. Pérez, 'Endesa se enfrenta a sanciones si ejecuta la amenaza de los cortes de luz', diarimes, 2019. https://www.diarimes.com/es/noticias/reus/2019/09/03/endesa enfrenta sanciones_si_ejecuta_amenaza_los_cortes_luz_68007_1092.html (accessed Mar. 10, 2020).

[38] H. Hassani, M. R. Yeganegi, C. Beneki, S. Unger, and M. Moradghaffari, 'Big Data and Energy Poverty Alleviation', Big Data and Cognitive Computing, vol. 3, no. 4, p. 50, 2019, doi: 10.3390/bdcc3040050. 